\title{
Present-day and future Antarctic ice sheet climate and surface mass balance in the Community Earth System Model
}

\author{
Jan T. M. Lenaerts ${ }^{1}$ (D) Miren Vizcaino ${ }^{2} \cdot$ Jeremy Fyke $^{3} \cdot$ Leo van Kampenhout $^{1}$ • \\ Michiel R. van den Broeke ${ }^{1}$
}

Received: 19 March 2015 / Accepted: 31 October 2015 / Published online: 1 February 2016

(c) The Author(s) 2016. This article is published with open access at Springerlink.com

\begin{abstract}
We present climate and surface mass balance (SMB) of the Antarctic ice sheet (AIS) as simulated by the global, coupled ocean-atmosphere-land Community Earth System Model (CESM) with a horizontal resolution of $\sim 1^{\circ}$ in the past, present and future (1850-2100). CESM correctly simulates present-day Antarctic sea ice extent, large-scale atmospheric circulation and near-surface climate, but fails to simulate the recent expansion of Antarctic sea ice. The present-day Antarctic ice sheet SMB

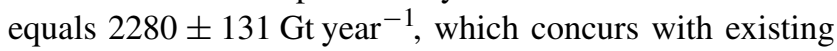
independent estimates of AIS SMB. When forced by two CMIP5 climate change scenarios (high mitigation scenario RCP2.6 and high-emission scenario RCP8.5), CESM projects an increase of Antarctic ice sheet SMB of about $70 \mathrm{Gt}$ year $^{-1}$ per degree warming. This increase is driven by enhanced snowfall, which is partially counteracted by more surface melt and runoff along the ice sheet's edges. This intensifying hydrological cycle is predominantly driven by atmospheric warming, which increases (1) the moisture-carrying capacity of the atmosphere, (2) oceanic source region evaporation, and (3) summer AIS cloud liquid water content.
\end{abstract}

Keywords Antarctica $\cdot$ Ice sheets $\cdot$ Surface mass balance $\cdot$ Climate modelling $\cdot$ Sea level $\cdot$ Climate change

Jan T. M. Lenaerts

j.lenaerts@uu.nl

1 Institute for Marine and Atmospheric Research Utrecht, Utrecht University, Princetonplein 5, 3584 CC Utrecht, The Netherlands

2 Department of Geoscience and Remote Sensing, Delft University of Technology, Delft, The Netherlands

3 Los Alamos National Laboratory, Los Alamos, NM, USA

\section{Introduction}

The Antarctic ice sheet (AIS) is the largest body of ice on Earth, with an ice volume equivalent to $58.3 \mathrm{~m}$ global mean sea level rise (Vaughan et al. 2013). Despite its remote location, being surrounded by the Southern Ocean, the ice sheet is nevertheless sensitive to recent climate change. For example, West Antarctica and the Antarctic Peninsula are among the fastest warming regions on Earth (Vaughan et al. 2003; Bromwich et al. 2012) and lose mass at significant rates (Sutterley et al. 2014; Mouginot et al. 2014). An increase in precipitation can buffer observed AIS mass loss (Frieler et al. 2015). As atmospheric temperature rises, the atmospheric column can hold more moisture, an effect that is especially pronounced at relatively low temperatures such as those over Antarctica (Pall et al. 2007). In recent years, parts of East Antarctica have been characterised by unusually frequent passages of strong short-termed precipitation events, so-called atmospheric rivers (Gorodetskaya et al. 2014); it is unclear however, whether this is due to natural variability or a manifestation of warming (Lenaerts et al. 2013). Modelling studies demonstrate that in the future, higher precipitation is to be expected over the AIS (Huybrechts et al. 2004; Krinner et al. 2007). However, these studies are restricted to atmosphere-only or intermediate-complexity climate models (Krinner et al. 2007; Huybrechts et al. 2011; Bengtsson et al. 2011), which lack the horizontal resolution required to represent the complex Antarctic ice sheet topography that is responsible for strong orographic precipitation (Lenaerts et al. 2012a), and to statistical (Agosta et al. 2013) or dynamic downscaling (Ligtenberg et al. 2013) of atmospheric reanalyses or global climate models. In contrast to Greenland, where increased snowfall currently does not compensate enhanced surface runoff, this increase in AIS snowfall translates almost 
fully to ice sheet mass gain and mitigation of sea-level rise (Bengtsson et al. 2011; Shepherd et al. 2012). The reason is that rainfall on the AIS remains small, and most of the liquid water produced by surface melt can refreeze in the snowpack. Even in a warmer future, projected surface runoff losses are dominated by mass gains through enhanced snowfall (Ligtenberg et al. 2013).

Recently, not only atmospheric but also oceanic changes have impacted the AIS. Antarctic peripheral ocean waters have warmed by $1-2 \mathrm{~K}$ in some regions (Arneborg et al. 2012), increasing the basal melt of floating ice shelves (Pritchard et al. 2012). The unexpected increase in Antarctic sea ice extent since 1979 could result from this increasing ice shelf basal melting (Bintanja et al. 2013), northern and tropical Atlantic ocean changes (Li et al. 2014), and/or natural variability (Polvani and Smith 2013). Another study shows that enhanced westerlies, associated with stratospheric ozone loss, could be responsible for the observed sea-ice expansion (Turner et al. 2009).

The combination of atmospheric and oceanic warming that has led to recent AIS changes underscore the need for a global coupled modelling framework (atmosphere, sea ice, ocean, and land ice) (Krinner et al. 2014), which should include a snow model for simulating a realistic snow albedo, metamorphosis and melt, and with multiple vertical layers, necessary to simulate percolation, refreezing and runoff of meltwater in the snowpack. Here, to address this need, we present output from the $\sim 1^{\circ}$ resolution Community Earth System Model (CESM), version 1.1.2. This model is forced solely by observed atmospheric greenhouse gases, volcanic, aerosol, and ozone concentrations since the start of the industrial revolution (18502005), and by future concentrations based on IPCC's AR5 strong climate change mitigation scenario (RCP2.6) and a business-as-usual scenario (RCP8.5), both until 2100.

This model set-up allows us to analyse the (recent) past, present-day, and future climate and surface mass balance (SMB) of the AIS, in the context of broader coupled system evolution.

This paper is structured as follows: in Sect. 2, we discuss the CESM model setup. Section 3 describes the evaluation of CESM-simulated Antarctic climate, sea-ice cover, and SMB. In Sect. 4, we present the modelled recent trends and future projections of Southern Ocean sea-ice cover and AIS SMB. The results are discussed and conclusions are drawn in Sect. 5.

\section{Model description and setup}

In this study we use the coupled version of the Community Earth System Model (CESM), version 1.1.2. This model uses the fifth generation of the Community Atmosphere Model [CAM5, Gettelman et al. (2010)], a land model [CLM4.5, Lawrence et al. (2011)], ocean model [POP2, Smith et al. (2010)] and sea ice model [CICE, Hunke and Lipscomb (2010)]. The model infrastructure is set up similarly to CESM simulations performed in the framework of CMIP5 (Meehl et al. 2013): the atmosphere and land model are run at a zonal versus meridional resolution of $0.9^{\circ} \times 1.25^{\circ}$, respectively, while the ocean and sea ice models have an approximate resolution of $1^{\circ}$. Vizcaíno et al. (2013) demonstrated that downscaled output of CESM realistically represents Greenland ice sheet climate and SMB, but CESM has not yet been evaluated for the AIS. The model used here differs from the Vizcaíno et al. (2013) setup in two important aspects.

Firstly, CAM4 has been replaced by CAM5, which includes updates in the cloud microphysics and dynamics schemes. CAM5 resolves a previously identified bias in CAM4, namely the excessive formation of liquid precipitation at sub-zero temperatures over the ice sheets (Vizcaíno et al. 2013). English et al. (2014) show that CAM5 considerably improves Arctic cloud characteristics relative to CAM4, although substantial biases remain in the representation of cloud liquid water.

Secondly, we limit absorption of shortwave radiation in the snowpack. CESM is one of the few CMIP5 models that include a multi-layered snow model and prognostically calculated snow albedo as a function of snow grain size (Flanner and Zender 2006). In a pilot study, we found that this configuration led to a significant overestimation of surface melt on Antarctica, with melt occurring at elevations up to $1500 \mathrm{~m}$ in East Antarctica. Future work is planned to resolve this; in the meantime, we limited the amount of subsurface absorption to $40 \%$, which resulted in a considerable improvement in the representation of surface melt over East Antarctica.

CLM contains a maximum of five layers of snow that can collectively contain up to one metre water equivalent (w.e.) of snow. To impose mass conservation within the framework of the global model, additional snowfall above the maximum snow thickness is immediately routed into the nearest ocean grid point, while at the same time being recorded as a positive mass flux. This method represents an ice sheet in mass balance, where mass input via SMB is balanced by equivalent ice calving at the ice sheet margin. Such schemes are common to many contemporary climate models, and implicitly assume an ice sheet that is in longterm mass balance, because on an annual basis, the excess mass routed to the ocean via the snow capping scheme is approximately equal to the mass of snow falling on the ice sheet. In the absence of a robust model to realistically simulate ice sheet-shelf interactions, Antarctic ice flow is not yet incorporated in CESM, unlike for Greenland (Lipscomb et al. 2013), and AIS topography is kept constant for the course of the simulation. Also the physical SMB downscaling onto a high-resolution ice sheet model grid 
Table 1 Comparison between CESM (historical, RCP2.6 and RCP8.5) and RACMO2 of Antarctic ice sheet area, near-surface temperature and SMB components

\begin{tabular}{|c|c|c|c|c|c|}
\hline \multirow[t]{2}{*}{ Component } & \multirow[t]{2}{*}{ Units } & \multirow{2}{*}{$\begin{array}{l}\text { RACMO2 } \\
1979-2005\end{array}$} & \multicolumn{3}{|l|}{ CESM } \\
\hline & & & $\begin{array}{l}\text { Historical } \\
1976-2005\end{array}$ & $\begin{array}{l}\text { RCP2.6 } \\
2070-2099\end{array}$ & $\begin{array}{l}\text { RCP8.5 } \\
\text { 2070-2099 }\end{array}$ \\
\hline Area & $10^{6} \mathrm{~km}^{2}$ & 13.93 & 13.85 & & \\
\hline Temperature & $\mathrm{K}$ & $238.2 \pm 0.6$ & $236.1 \pm 0.4$ & $238.0 \pm 0.5$ & $241.0 \pm 0.8$ \\
\hline Snowfall & Gt year $^{-1}$ & $2829 \pm 122$ & $2428 \pm 135$ & $2721 \pm 108$ & $3239 \pm 171$ \\
\hline Rainfall & Gt year $^{-1}$ & $6 \pm 2$ & $5 \pm 2$ & $12 \pm 3$ & $44 \pm 14$ \\
\hline Surface melt & Gt year $^{-1}$ & $88 \pm 24$ & $203 \pm 41$ & $309 \pm 62$ & $708 \pm 138$ \\
\hline Surface runoff & Gt year $^{-1}$ & $5 \pm 2$ & $86 \pm 21$ & $153 \pm 22$ & $475 \pm 118$ \\
\hline Sublimation & Gt year $^{-1}$ & $228 \pm 11^{\mathrm{a}}$ & $68 \pm 6$ & $76 \pm 5$ & $104 \pm 8$ \\
\hline SMB & Gt year $^{-1}$ & $2596 \pm 121$ & $2280 \pm 131$ & $2504 \pm 110$ & $2703 \pm 121$ \\
\hline
\end{tabular}

${ }^{a}$ Includes drifting snow sublimation

(Vizcaíno et al. 2013) is-so far-inactive for Antarctica, and the SMB output is generated and analyzed at the original model resolution $\left(0.9 \times 1.25^{\circ}\right)$. Given the size of Antarctica and the absence of narrow ablation zones (such as those that exist around the Greenland periphery), this likely is a reasonable assumption.

Ice sheet extent and topography are derived from the Antarctic Digital Database Version 5.0 (http://www.add. scar.org). In CESM, floating ice shelves are ascribed the same surface characteristics as grounded ice. The area of the Antarctic ice sheet in CESM is 13.84 million $\mathrm{km}^{2}$ (Table 1), which is realistic and enables a direct evaluation of AIS-integrated SMB in CESM. Note, however, that we have included ice shelves into the CESM AIS mask, and that as such the reported SMB changes on ice shelves cannot be directly translated into sea level changes. This approach is motivated by the CESM horizontal grid resolution that is too coarse to discriminate narrow floating parts from grounded parts in certain regions of the ice sheet.

To generate initial conditions for the transient experiment starting in 1850, we took ocean and land data from the CESM Large-Ensemble control run (Kay et al. 2014) after 1500 years of simulation, which we continued for an additional 130 years of constant pre-industrial forcing to spin up the ice sheet snowpack (which is not represented in the CESM Large Ensemble simulations). From this initial condition, we followed the transient forcing strategy as proposed by the CMIP5 experimental design (Taylor et al. 2007): forcing the model solely with observed, time-varying concentrations of atmospheric greenhouse gases, aerosols, and ozone, volcanic activity and insolation variations from 1850 until 2005. Then, from 2006 onwards, we forced CESM with two strongly differing climate change scenarios: RCP2.6, a strong mitigation and adaptation scenario, with a resulting global mean warming of $<2 \mathrm{~K}$ in the twenty-first century; and RCP8.5, in which present-day anthropogenic emissions of greenhouse gases continues unabatedly, leading to a strong global average warming of $\sim 5 \mathrm{~K}$ by the end of the twenty-first century (Meehl et al. 2013). Although arguably the RCP2.6 scenario has already been surpassed in recent years (Sanford et al. 2014), it is included to assess the impact of a 'best-case' policy change on future Antarctic ice sheet climate and its contribution to future sea level change from surface processes.

In-situ measurements of near-surface climate on Antarctica are sparse. In addition, the chronology of year-to-year variability within CESM does not match that of observations given that CESM is a freely-evolving global coupled model. Therefore we can only compare CESM with observations on climatological (>20 year) time scales, which further reduces the availability of observations. As an alternative evaluation of the present-day climate and SMB, we compare CESM results to ERA-Interim, the latest iteration of atmospheric reanalyses from the European Center of Medium-Range Weather Forecasting [ECMWF, Dee et al. (2011)], and to regional atmospheric model RACMO2 (Van Wessem et al. 2014) which has been compared favourably to available in-situ measurements of AIS wind speed, temperature and SMB (Lenaerts et al. 2012a; Sanz Rodrigo et al. 2012; Van Wessem et al. 2014). Both ERA-Interim and RACMO2 provide gridded products for the period 1979-2005, with the advantage of RACMO2 having a finer spatial resolution $\left(\sim 0.25^{\circ}\right)$ than ERA-Interim: $\left(\sim 0.75^{\circ}\right)$.

\section{Evaluation of CESM}

\subsection{Large-scale atmospheric circulation}

Large-scale atmospheric circulation not only controls present-day Antarctic climate (Van den Broeke 1998) but also 


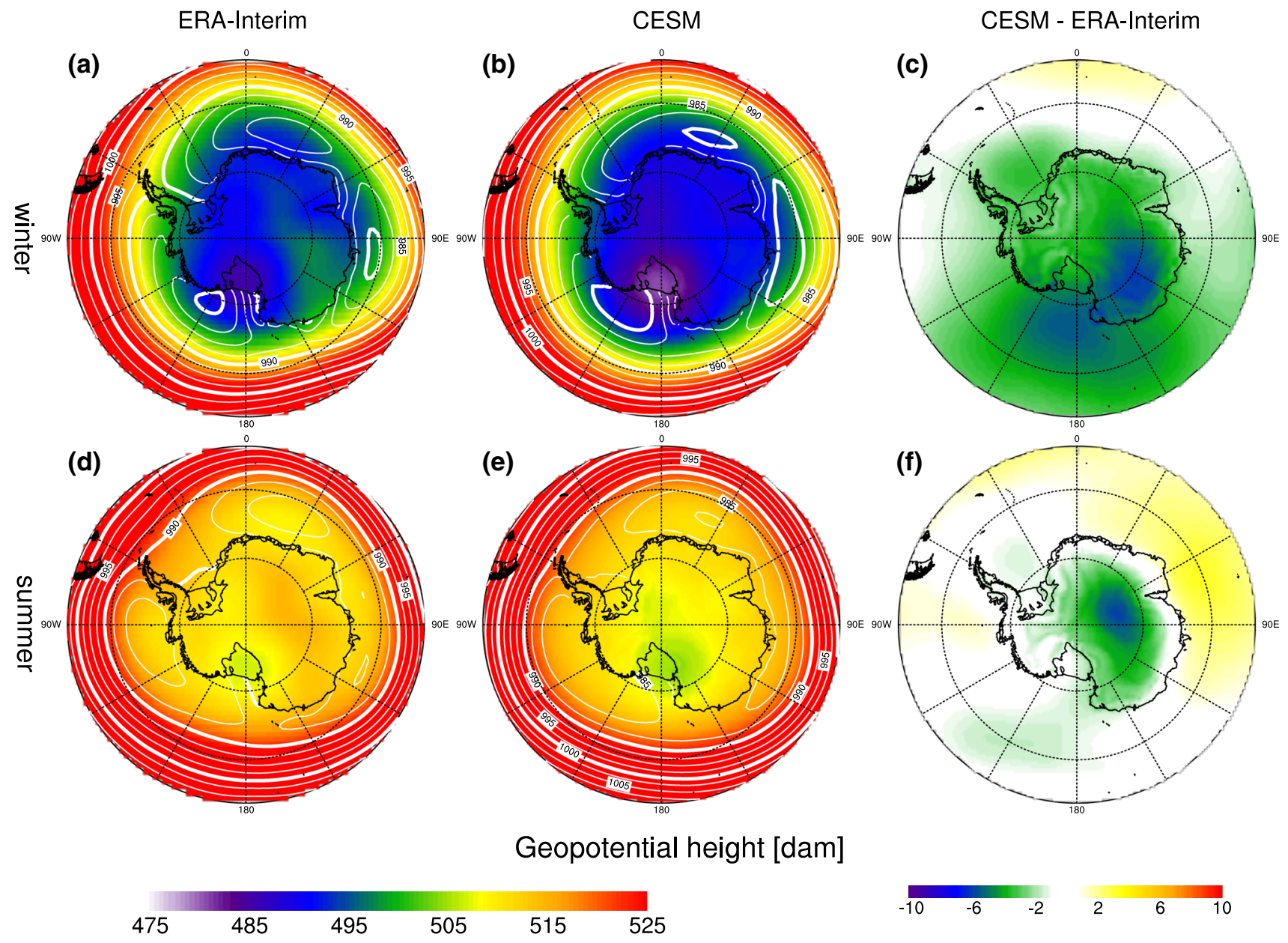

Fig. 1 Mean large-scale atmospheric circulation from ERA-Interim (1979-2005, left), and historical CESM (1976-2005, center), and difference between CESM and ERA-Interim (right) in winter (JJA, top)

AIS dynamics on glacial-interglacial time scales (DeConto et al. 2007). Poleward heat advection is strongest in areas eastward of the climatological low-pressure systems, where the mean atmospheric flow is directed onto the ice sheet, e.g. Dronning Maud Land and the Amundsen Sea coast. During sea ice free conditions, this atmospheric flow takes up moisture from the relatively warm ocean surface waters before reaching the ice sheet, leading to precipitation, whereas the presence of sea ice limits evaporation and leads to drier conditions on the ice sheet (Genthon et al. 2005; Krinner et al. 2008; Simmonds and Wu 1993).

In Fig. 1 we compare the annual mean mid-troposphere $(500 \mathrm{hPa})$ and surface pressure distributions from CESM (last 30 years of historical simulation, 1976-2005) with ERA-Interim (1979-2005). The upper atmospheric flow at $500 \mathrm{hPa}$ (colours in Fig. 1) is mainly zonal and symmetric around Antarctica with few continental barriers that disturb and summer (DJF, bottom). In $\mathbf{a}, \mathbf{b}, \mathbf{d}$, and $\mathbf{e}$, the white contours represent surface pressure $(\mathrm{hPa})$ and the colours represent the geopotential heights at $500 \mathrm{hPa}(\mathrm{dam})$

it, apart from the South American Andes and the Antarctic Peninsula. Three climatological low-pressure systems are found north of the ice sheet, with a circular-shaped polar vortex that is found higher in the atmosphere, where it is most strongly developed in winter. The structure and seasonal cycle of the geopotential height of the $500 \mathrm{hPa}$ level of CESM compares well with that of ERA-Interim, although geopotential heights are underestimated over and near the continent in winter (2-7 dam, Fig. 1c) and over the high interior of the AIS in summer (up to 6 dam, Fig. 1f). The simulated surface pressure patterns appear realistic, with the three known climatic low pressure systems identifiable in CESM near Dronning Maud Land $\left(\sim 30^{\circ} \mathrm{E}\right)$, along Queen Mary Land $\left(\sim 90^{\circ} \mathrm{E}\right)$ and in the Amundsen Sea $\left(\sim 150^{\circ} \mathrm{W}\right)$. Also at the surface, however, CESM tends to underestimate the central pressure in these low-pressure systems (Fig. 1). 


\subsection{Sea ice}

In contrast to the Arctic, where sea ice area has declined with a rate of $4.6 \%$ per decade [1979-2013, updated data from Cavalieri et al. (1996)], Antarctic sea ice has expanded during the last 35 years (1.9\% per decade, Fig. 2). CESM agrees with the mean sea ice extent during the observational period $\left[10.7 \pm 0.3\right.$ million $\mathrm{km}^{2}$ in CESM (1976-2005) vs. $10.8 \pm 0.5$ million $\mathrm{km}^{2}$ in the observations (1979-2005)], but the model shows a decreasing sea ice extent in that time frame ( - $2 \%$ per decade). This result is consistent with the 30 members of the CESM Large-Ensemble (LENS) experiment (Kay et al. 2014), all of which show a decreasing Antarctic sea ice trend (Fig. 2). The same holds for the CMIP5 climate model ensemble (Zunz et al. 2013) and is therefore certainly not unique.

The annual sea-ice minimum (in February) and maximum (in September) (see Fig. 2), defined here as $>50 \%$ of the grid cell covered with sea ice, from ERA-Interim (i.e. satellite-derived) and CESM are depicted in Fig. 3 as black lines. CESM simulates the spatial pattern of September sea ice cover well, although September total sea ice area $\left(\sim 16\right.$ million $\left.\mathrm{km}^{2}\right)$ is underestimated (Fig. 2) compared to the observations ( $>18$ million $\mathrm{km}^{2}$, inset Fig. 2). In contrast to the observations, CESM does not simulate significant sea ice along major parts of the East Antarctic coast after the summer. Moreover, CESM's late summer sea ice is too extensive in the Ross, Bellinghausen and Weddell Seas (Fig. 3). In an area-integrated sense, however, the February extent compares well with observations (inset Fig. 2).

\subsection{Near-surface climate}

Close to the surface, the Antarctic wind field is driven by an interplay between large-scale (synoptic) and katabatic forcings (Van den Broeke et al. 2003; Sanz Rodrigo et al. 2012). The strongest winds are found in coastal East Antarctica, where the steep slopes and favourable large-scale pressure gradient intensify katabatic winds. Although CESM is able to reproduce the location of the wind maxima that are shown by RACMO2 (Fig. 3), the wind speed is generally underestimated $\left(\mathrm{R}^{2}=0.41\right.$, mean bias $\left.=-2.1 \mathrm{~m} \mathrm{~s}^{-1}\right)$. This is presumably related to the horizontal resolution, smoothing of topography, and the vertical resolution of the atmospheric model, which is insufficient in the lower atmospheric boundary layer to represent extreme temperature inversions and related katabatic wind maxima, but it could also be due to the effect of parametrized mountain roughness that is exaggerated in CAM5 (Lindvall et al. 2013).

Annual mean near-surface temperatures (Fig. 3) are strongly determined by elevation, with the lowest temperatures $(<225 \mathrm{~K})$ in the high-elevation interior of Antarctica ( $>2000 \mathrm{~m}$ above sea level), increasing towards the coasts,

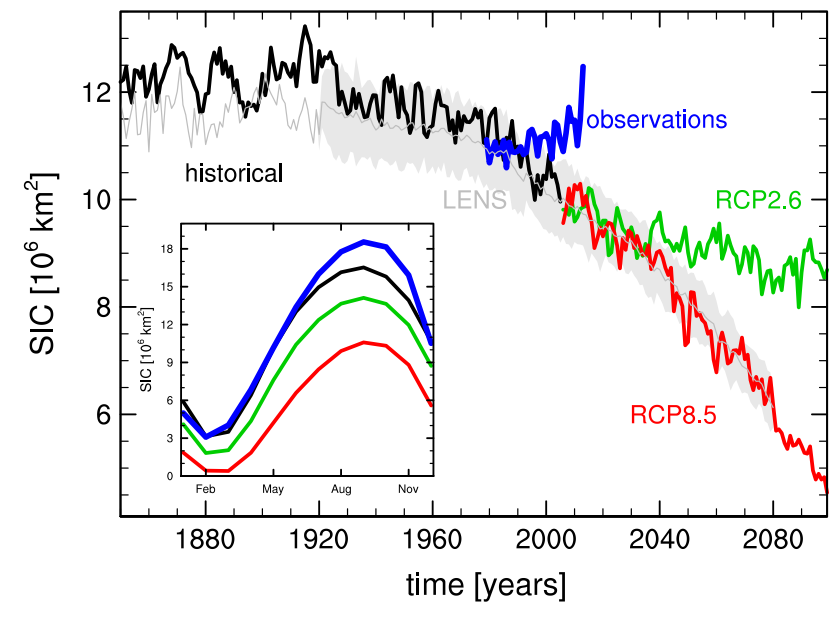

Fig. 2 Time evolution of annual mean Antarctic sea ice cover, in million $\mathrm{km}^{2}$. Black represents historical CESM, green RCP2.6 and red RCP8.5. The CESM Large Ensemble (LENS) is shown in grey, with the grey band representing the standard deviation of the 30 members (1920-2080). Before 1920, only the first ensemble member is shown. In blue the observations [National Snow and Ice Data Center, Cavalieri et al. (1996)]. The inset shows the mean seasonal cycle of the different datasets

where annual mean temperatures generally exceed $250 \mathrm{~K}$. Compared to RACMO2, the near-surface temperature distribution is realistically simulated by CESM (Fig. 3), with a squared correlation coefficient $\mathrm{R}^{2}$ that equals 0.95 and a mean bias of $-2.1 \mathrm{~K}$. Despite this overall underestimation of temperatures, especially near the coast, CESM near-surface temperatures are biased positive on the Antarctic Plateau $(1-5 \mathrm{~K})$. This is possibly due to the above-mentioned poorly resolved temperature inversions which are well developed in these regions, especially in winter (King et al. 2001).

Near-surface temperature is largely determined by the surface energy balance (SEB), the sum of the incoming and outgoing heat fluxes at the snow surface. Long-term, reliable surface radiation and energy balance (SEB) components are only available from a single coastal station (Neumayer base, 1993-2007, Fig. 4b). We evaluate the ice-sheet wide CESM SEB by comparing simulated mean surface temperatures (which are directly coupled to the SEB) with observed $10 \mathrm{~m}$ deep snow temperatures measured in boreholes at 64 sites, which approximates the long-term annual mean surface temperature (Van den Broeke 2008; Fig. 4a). Although CESM simulates surface temperatures well in the high interior, those in lower-lying areas near the ice sheet periphery are generally underestimated $\left(R^{2}=0.94\right.$, mean bias $=-2.4 \mathrm{~K}$, root mean square error $=4.1 \mathrm{~K}$ ). Analysis of the SEB components at a coastal location shows that the net radiation $\left(\mathrm{R}_{\mathrm{net}}\right)$ is underestimated by CESM throughout most of the year, due to a persistent underestimation (10$15 \mathrm{~W})$ in longwave radiation $\left(\mathrm{LW}_{\text {net }}\right)$, a well known bias 
Fig. 3 Mean near-surface $\mathbf{a}, \mathbf{b}$ wind speed (at $10 \mathrm{~m}$ above the surface, uppermost panels) and c, $\mathbf{d}$ temperature $(2 \mathrm{~m}$ above the surface, lowermost panels) from RACMO2 [1979-2005, (a, c)] and historical CESM [19762005, (b, d)]. The $50 \%$ sea ice cover in February (dashed line) and September (solid line) according to the observations (left) and CESM (right) is also shown for the same periods
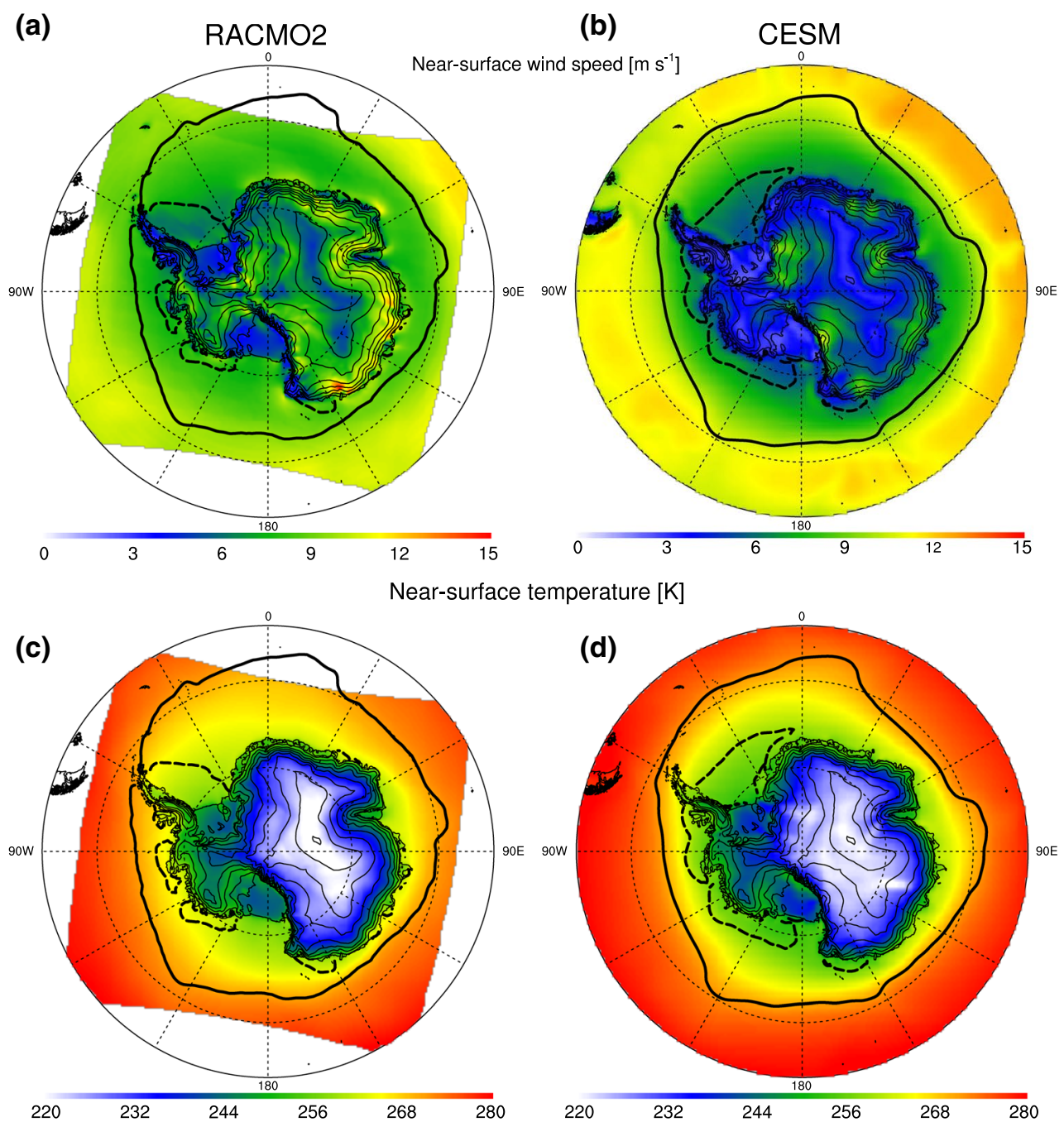

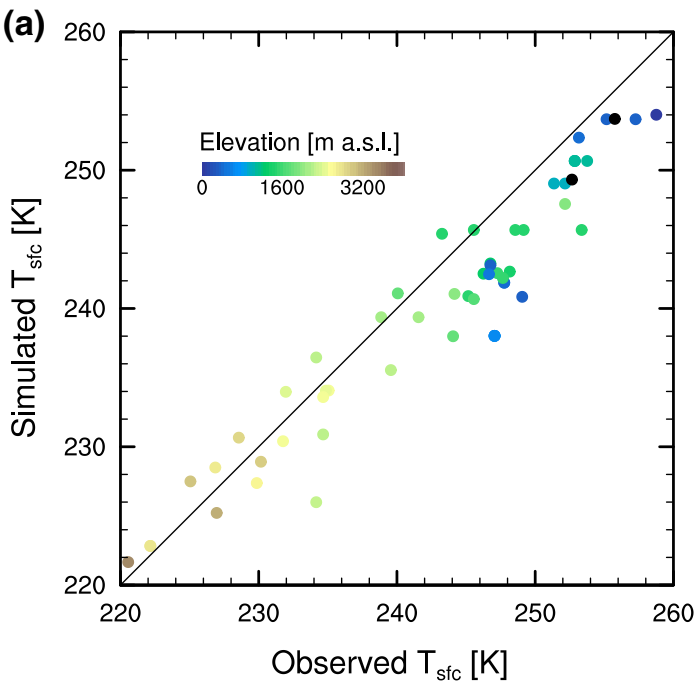

Fig. 4 a Observed versus simulated surface temperatures at 64 locations on the AIS (Van den Broeke 2008). The colors of the dots represent the elevation of each measurement. b Seasonal cycle of SEB fluxes at Neumayer $\left(\mathrm{SW}_{\text {net }}\right.$, net shortwave radiation; $\mathrm{LW}_{\text {net }}$, net long-

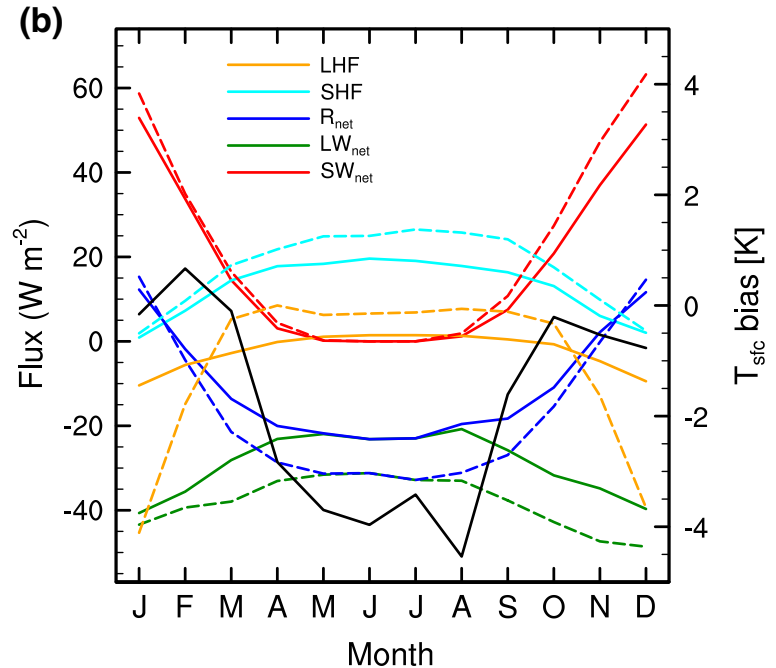

wave radiation; $R_{\text {net }}$, net radiation; $S H F$, sensible heat flux; LHF, latent heat flux) according to the observations (Lenaerts et al. 2010) (solid lines) and CESM (1976-2005, dashed lines). The surface temperature bias in CESM is shown by the black line (right axis) 


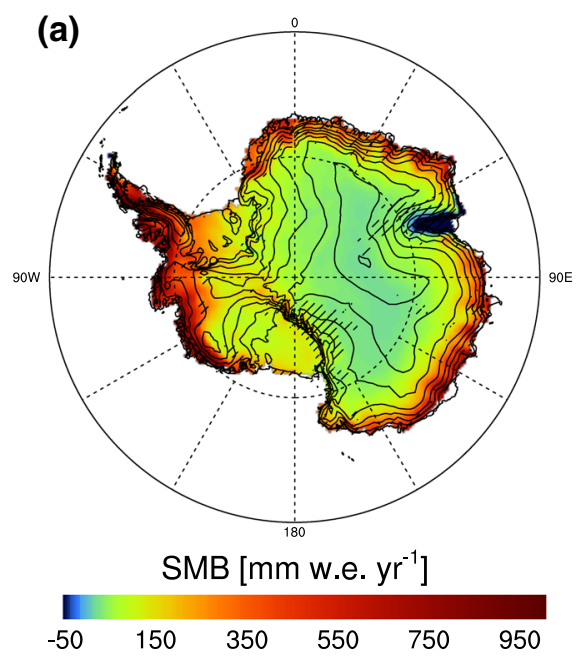

Fig. 5 a Mean SMB from the historical CESM (1976-2005). In the dashed areas, the CESM SMB is $>50 \%$ different from the RACMO2 SMB (1979-2005). b Scatter of observed, "A"-rated (Favier et al. 2013) versus CESM historical (mean of 1976-2005) SMB (closest grid point located on the ice sheet), binned in $400 \mathrm{~m}$ elevation intervals. The vertical lines and grey area depict the varia-

shared by many polar climate models (Tjernström et al. 2008; Lenaerts et al. 2012b; Barton et al. 2014). This LW underestimation, despite of a partial compensation by an overestimation of shortwave radiation (summer) and sensible heat flux (winter), results in a negative bias in surface temperature simulated by CESM, peaking in winter (up to $4-\mathrm{K})$.

\subsection{Surface mass balance}

Given realistic simulation of large-scale and near-surface climate characteristics by CESM, we can further analyse its performance in representing the Antarctic ice sheet SMB. A map of CESM-simulated 1976-2005 annual mean SMB is shown in Fig. 5, and its main components are presented in Fig. 6. SMB is high $\left(>500 \mathrm{~mm}^{\text {w.e. }}\right.$ year $^{-1}$ ) along the Antarctic coasts, especially in West Antarctica and the Antarctic Peninsula, and gradually decreases towards the high-elevation ice sheet interior, where SMB $<100 \mathrm{~mm}$ w.e. year ${ }^{-1}$. Regions where CESM SMB significantly $(>50 \%)$ diverges from RACMO2 are the Amery ice shelf $\left(\sim 70^{\circ} \mathrm{E}\right)$ and the Transantarctic Mountains west of the Ross ice shelf. In the latter region, CESM simulates higher SMB in comparison to RACMO2, presumably because it does not adequately represent the complex topography, thereby underestimating the precipitation shadow of the mountain range. On the other hand, RACMO2 is too dry in this area in comparison to observations (Stearns 2011; Rignot et al. 2011). On the Amery ice shelf, we know that negative-SMB areas (i.e. blue ice)

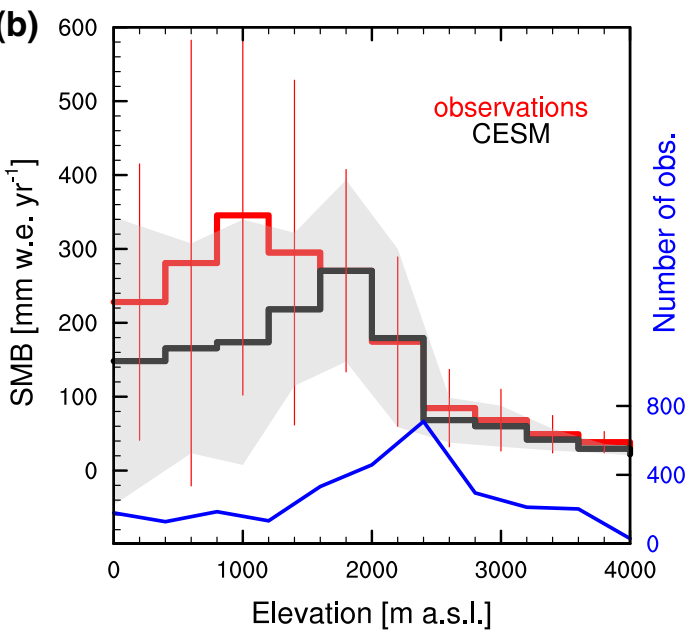

bility (two standard deviations) of the observations and CESM within each elevation bin, respectively. The number of "A"-rated observations in each elevation bin is depicted by the blue line (right axis). The lowest amount of observations $(<100)$ are available for the low and high elevation bins, with a high number of observations in the bins between 1600 and $2800 \mathrm{~m}$ a.s.1

exist (Lenaerts et al. 2012a), but their extent is largely overestimated in CESM due to too little snowfall (in comparison with RACMO2), which reveals the ice surface early in summer and activates the melt-albedo feedback. With ice (albedo $=0.5$ ) present at the surface throughout virtually the entire summer, mass loss by sublimation and surface melt are overestimated. Figure $5 \mathrm{~b}$ shows that CESM, compared to the in-situ observations, generally underestimates SMB in areas below $1500 \mathrm{~m}$, although it is well within the range of the observational variability $\left(\mathrm{R}^{2}=0.79\right.$, mean bias $=-40 \mathrm{~mm}$ w.e. year $^{-1}$, root mean square error $=40 \mathrm{~mm}$ w.e. year $^{-1}$ ). For elevations $>1500 \mathrm{~m}$, the model is well able to simulate the sharp decline in SMB with elevation, as well as the magnitude of the SMB $\left(<50 \mathrm{~mm}\right.$ w.e. year $\left.^{-1}\right)$ in the high-elevation ice sheet interior.

The SMB in the interior ( $>2500 \mathrm{~m}$ elevation) is mainly determined by snowfall (Fig. 6), as interior sublimation and surface melt are small. Sublimation is mainly important in coastal East Antarctica, where winds are strong and the near-surface air is dry. Surface melt is confined to the lowermost areas of the ice sheet and the ice shelves. Highest surface melt is found on and around Amery ice shelf and on the eastern Antarctic Peninsula ice shelves. Integrated over AIS (Table 1, including ice shelves), contemporary CESM SMB equals $2290 \pm 131 \mathrm{Gt} \mathrm{year}^{-1}$, which is lower than the RACMO2 SMB $\left(2596 \pm 121 \mathrm{Gt}^{\text {year }}{ }^{-1}\right)$, but agrees with other, independent estimates within the uncertainties (Vaughan et al. 1999; Lenaerts et al. 2012a). The largest part of the difference between CESM and RACMO2 

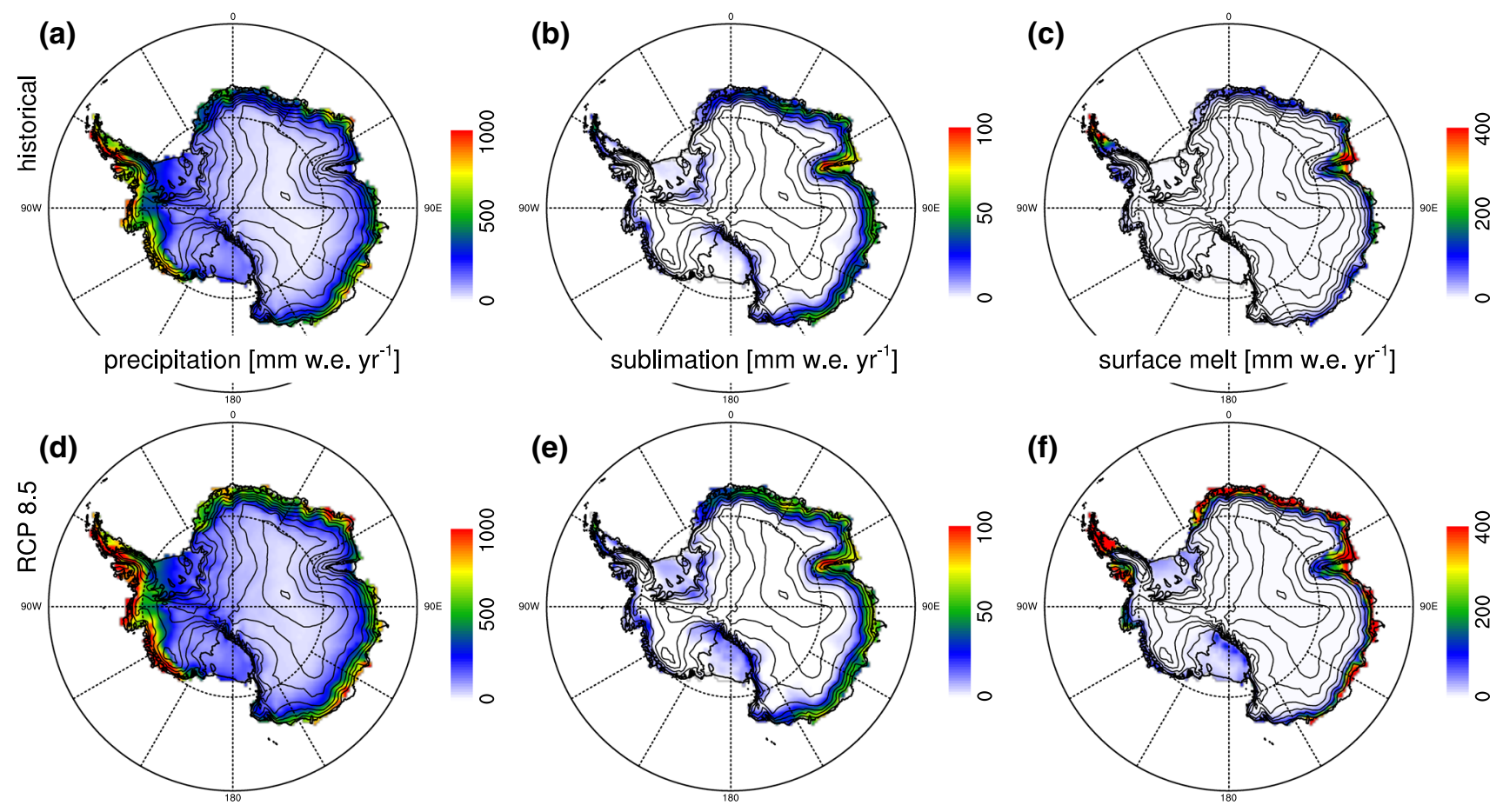

Fig. 6 Spatial distribution of $\mathbf{a}, \mathbf{d}$ precipitation, $\mathbf{b}, \mathbf{e}$ sublimation, and $\mathbf{c}, \mathbf{f}$ surface melt on Antarctica, all in mm w.e. per year, according to historical CESM [1976-2005, (a-c)] and CESM RCP8.5 [2070-2099, (d-f)]. Note the different scales of the legends

$\left(\sim 300 \mathrm{Gt}_{\mathrm{year}}{ }^{-1}\right)$ is found for the grounded ice sheet, where the SMB in CESM equals $2007 \pm 119 \mathrm{Gt} \mathrm{year}^{-1}$ in CESM, versus $2250 \pm 111 \mathrm{Gt}^{-1} \mathrm{r}^{-1}$ in $\mathrm{RACMO} 2$. SMB is dominated by mass gain through solid precipitation $\left(2428 \pm 135\right.$ Gt year $\left.^{-1}\right)$, with sublimation $\left(68 \pm 6 \mathrm{Gt}\right.$ year $\left.^{-1}\right)$ and runoff $\left(86 \pm 21 \mathrm{Gt}\right.$ year $\left.^{-1}\right)$ contributing to surface mass loss. Rainfall is negligible. The lower SMB in CESM in comparison with RACMO2 is mainly explained by lower precipitation ( -300 Gt year $\left.{ }^{-1}\right)$ and higher runoff $\left(\sim 75 \mathrm{Gt} \mathrm{year}^{-1}\right)$, slightly compensated for through less sublimation ( $-150 \mathrm{Gt} \mathrm{year}^{-1}$ ) because drifting snow is considered in RACMO2 (Lenaerts et al. 2012a) and not in CESM. The underestimation of precipitation might be related to lower atmospheric model resolution in CESM compared to RACMO2, since precipitation in Antarctica is predominantly generated by orographic lifting (Lenaerts et al. 2014).

Meltwater runoff, equal to about $4 \%$ of the SMB, which should essentially be zero according to RACMO2 because all meltwater refreezes in the cold firn (Magand et al. 2008; Kuipers Munneke et al. 2012), is overestimated in CESM because of two reasons. Firstly, meltwater production is excessive because the net energy available for melt is overestimated. Secondly, the limited depth (i.e. $1 \mathrm{~m}$ w.e.) of the snowpack in CESM limits the potential for refreezing; in reality, the Antarctic firn pack is from ten to more than one hundred metres thick (Van den Broeke 2008).

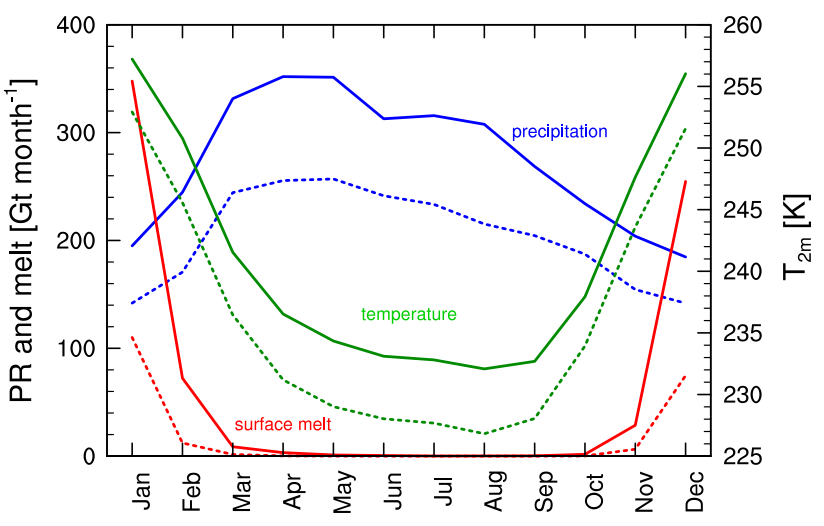

Fig. 7 Seasonal cycle of Antarctic ice sheet area-integrated precipitation (blue), surface melt (red), and area-averaged near-surface temperature (green) according to CESM historical (1976-2005, stippled) and CESM RCP8.5 (2070-2099, solid)

Figure 7 illustrates the high seasonal variability of both integrated precipitation and melt in CESM. The long winter season (March-August) is characterised by high precipitation (10-50 Gt month ${ }^{-1}$ above average), peaking in autumn. The seasonal cycle is driven by the semi-annual oscillation (van Loon 1967) and enhanced ocean evaporation coinciding with the annual sea ice minimum. Melt only occurs in the short summer season (November-February), when precipitation is significantly lower than in 
winter. The seasonal cycle of precipitation in CESM agrees with RACMO2 within the uncertainties (Fig. 8). Summer melt volume is overestimated in CESM in comparison to RACMO2 (Table 1; Fig. 8), although it should be noted that the latter somewhat underestimates meltwater production in comparison to satellite products (Trusel et al. 2013).

\section{Recent trends and future projections}

CESM-simulated Antarctic SMB exhibits no significant trend from 1850 to $\sim 1960$, and is characterised by considerable interannual and interdecadal variability (Fig. 9). From the 1960's onwards, the simulated SMB progressively increases, and exceeds natural variability at the end of the historical period (Fig. 9), which contradicts with existing best estimates of present-day SMB (Lenaerts et al. 2012a). The weak (RCP2.6) and strong (RCP8.5) climate warming scenario agree on a further SMB increase in the first part of the twenty-first century, which tapers off in the second half of the century in RCP2.6 but continues in RCP8.5 (Fig. 9; Table 1). The SMB at the end of the century (2070-2099) increases to $2504 \pm 119(\sim 10 \%)$ in RCP2.6 and $2703 \pm 121(\sim 19 \%)$ in RCP8.5. In agreement with existing studies, this SMB increase is strongly positively correlated with an increase of Antarctic ice sheet mean near-surface temperature (inset of Fig. 9). In the RCP2.6 simulation, the temperature increases $\sim 2 \mathrm{~K}$ throughout the twenty-first century, whereas the temperature increase over the same period is more than $4 \mathrm{~K}$ in the RCP8.5 simulation (Fig. 9). Dividing the SMB change by the temperature increase results in $70 \mathrm{Gt} \mathrm{K}^{-1}$ for both scenarios, a value that is smaller than that in existing literature (Ligtenberg et al. 2013; Frieler et al. 2015), because in CESM, enhanced runoff offsets Antarctic surface mass gain by precipitation (which equals 99 and $165 \mathrm{Gt} \mathrm{K}^{-1}$ in RCP2.6 and RCP8.5, respectively). Since CESM overestimates present-day runoff from surface melt and the limited pore space available in the shallow CESM snowpack, the simulated future SMB is potentially underestimated due to excessive surface runoff, especially in the strong warming scenario (RCP8.5). Contrary to Greenland (Fyke et al. 2014), interannual SMB variability does not increase in the future: whereas future Greenland ice sheet SMB variability is increasingly dominated by high-variability melt and runoff, snowfall remains the dominant driver of SMB and its variability in Antarctica.

In the CESM RCP8.5 simulation, atmospheric temperature increases in all seasons, with the greatest increase in winter (Fig. 7). As a result of the strong temperature-precipitation relation on Antarctica (Ligtenberg et al. 2013), the precipitation increase resembles the present-day seasonal

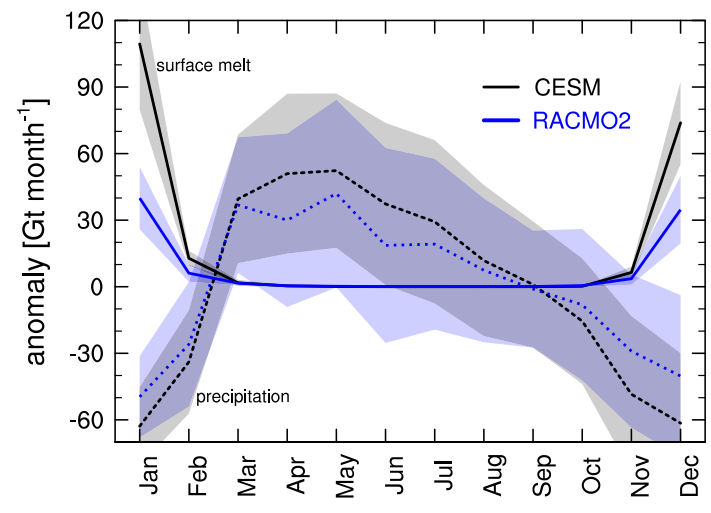

Fig. 8 Monthly anomaly (w.r.t annual mean) of Antarctic ice sheet area-integrated precipitation (stippled) and surface melt (solid), both in Gt per month, according to historical CESM (1976-2005) and RACMO2 (1979-2005). The shading represents interannual variability (the width is equal to two standard deviations)

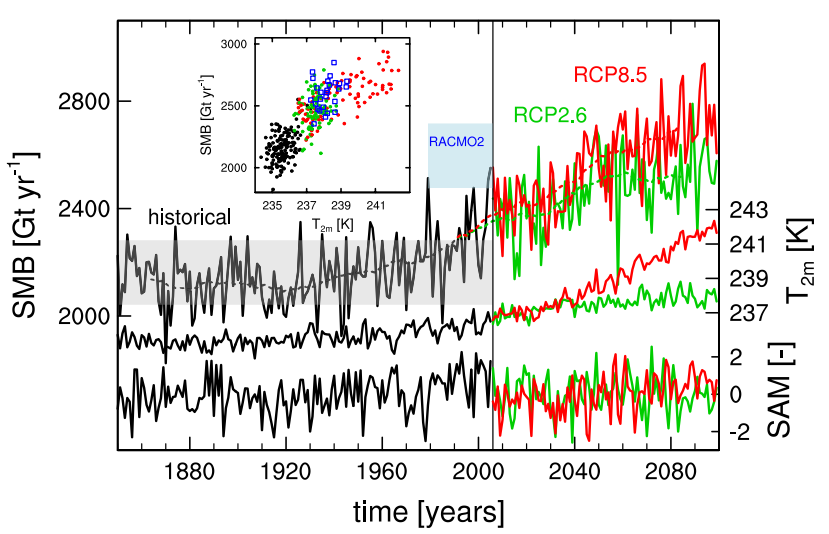

Fig. 9 Time evolution (1850-2099) of annual Antarctic ice sheet area-integrated SMB (upper curve), area-averaged near-surface temperature (middle curve), and annual southern annular mode (lower curve, SAM, defined as the normalised zonal averaged surface pressure difference between $40^{\circ} \mathrm{S}$ and $65^{\circ} \mathrm{S}$ ) according to CESM historical (black), CESM RCP2.6 (green) and CESM RCP8.5 (red). The mean \pm standard deviation of the RACMO2 SMB (1979-2005) is illustrated by the blue box. The inset shows the SMB versus Antarctic mean near-surface temperature

cycle, with the largest absolute $\left(\sim 110 \mathrm{Gt}_{\text {month }^{-1}}\right)$ and relative increases $(\sim 50 \%)$ in early winter, and the small-

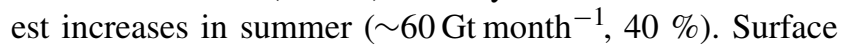
melt also increases strongly, by a factor of four over summer (Fig. 7). Both precipitation and melting demonstrate a strong and non-linear reaction to atmospheric temperature changes. The cumulative effects of more precipitation in winter and more surface melt/runoff in summer suggest that the amplitude of the seasonal cycle of SMB will increase in the future, and that seasonal extremes in SMB components (snowy winters and warm, melt-rich summers) will occur more regularly in the future. 
To analyse this in further detail, we compare the distribution of monthly SMB values from the last 30 years in the historical simulation (1976-2005) to monthly SMB values from the last 30 years in the RCP simulations (2070-2099), for West Antarctica and East Antarctica separately. These monthly values are fitted to a generalised extreme value (GEV) distribution to analyse their statistical characteristics. GEV is a family of mathematical expressions originating from the extreme value theory, a statistical framework to analyse rare or extreme events in e.g. climate model data (Kharin et al. 2010). The fitted distributions (depicted in Fig. 11) clearly show the different characteristics of West and East Antarctic SMB and its response to global warming. In West Antarctica, where mean monthly SMB increases from $66 \mathrm{Gt} \mathrm{month}^{-1}$ in the historical period to $75 \mathrm{Gt}^{\text {month }^{-1}}{ }^{\text {in RCP2 }} .6$ and $85 \mathrm{Gt}^{\text {month }}{ }^{-1}$ in RCP8.5, the future distributions display an increasingly heavy left tail. This is the signature of the relatively mild summers on West Antarctica that lead to surface melt and associated runoff, especially on the Antarctic Peninsula ice shelves. Thus, despite an overall West Antarctic SMB increase, there is a two to sixfold increase in the probability of negative monthly SMB $(0.2 \%$ in the historical period, $0.4 \%$ in RCP2.6 and $1.2 \%$ in RCP8.5). Remarkably, the response to atmospheric warming is reversed in East Antarctica, considering the heavy right tail. When mean monthly SMB increases from $95 \mathrm{Gt}^{\text {month }}{ }^{-1}$ in the historical period to $106 \mathrm{Gt} \mathrm{month}^{-1}$ in RCP2.6 and $117 \mathrm{Gt}^{\text {month }}{ }^{-1}$ in RCP8.5, the right tail, which is heavier than for West Antarctica becomes even heavier in the future simulations. This suggests that high-SMB months (i.e. months with anomalously high snowfall) are projected to occur more frequently. For example, a monthly SMB exceeding 145 Gt has a probability of $1 \%$ in the historical period (i.e. occurring each $\sim 9$ years), which increases to $4 \%$ in RCP2.6 and to $20 \%$ in RCP8.5. These results indicate that, although the mean East Antarctic SMB increase scales linearly with atmospheric warming, the probability of extremely high snowfall episodes tends to grow in a stronger than linear fashion.

An outstanding question is: what drives the overall area-integrated Antarctic SMB increase? Previous work has concluded that large-scale atmospheric circulation on and around the Antarctic ice sheet is projected to remain relatively unchanged in a future warming climate (Krinner et al. 2014), or even slightly reduces in strength in the future (Grieger et al. 2015). Indeed, the Southern Annual Mode, which represents the strength of the westerlies north of Antarctica (Marshall et al. 2006; Visbeck 2009), does not significantly change in the CESM projections presented here (Fig. 9). This suggests that future AIS SMB changes, rather than changes in large-scale atmospheric circulation, are driven by atmospheric warming. We discuss three mechanisms behind this.

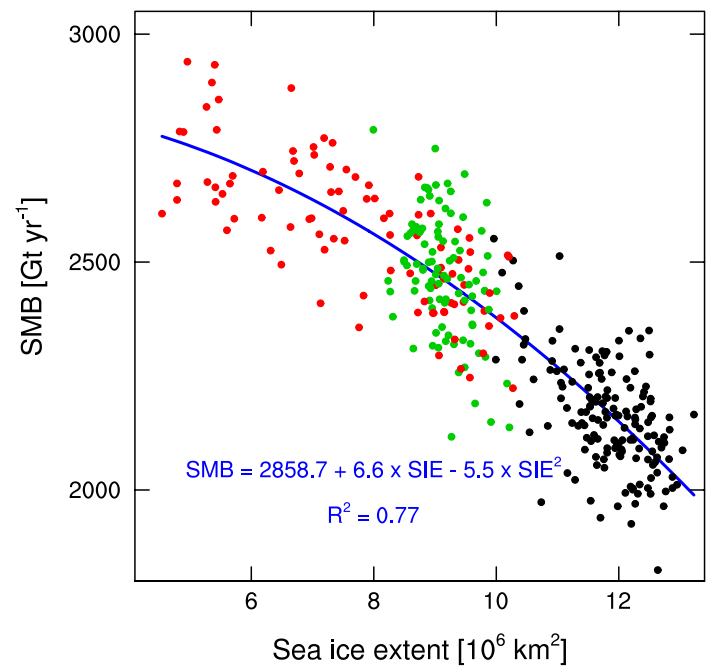

Fig. 10 Scatter plot of annual mean Antarctic sea ice extent versus Antarctic SMB, according historical CESM (1850-2005, black), RCP2.6 (2006-2099, green), and RCP8.5 (2006-2099, red). Best second-order polynomial fit (SIE, sea ice extent) and corresponding squared correlation coefficient $\mathrm{R}^{2}$ is given in blue

First of all, atmospheric warming leads to a further decrease in sea ice cover around Antarctica (Fig. 2); the CESM RCP8.5 scenario predicts that by the end of this century, most of the East Antarctic ice sheet coast would be sea ice free. The only regions with permanent sea ice cover remaining would be the Ross and Weddell Seas, which are located adjacent to the large ice shelves. Figure 10 shows a negative correlation between integrated Southern Hemisphere sea ice extent and Antarctic SMB in all CESM simulations, despite considerable scatter. The largest increase in SMB is found in coastal Dronning Maud Land $\left(0-30^{\circ} \mathrm{E}\right.$, $71-76^{\circ} \mathrm{S}$, Fig. 12). Unlike other coastal areas in East Antarctica, Dronning Maud Land receives precipitation frequently, because it is located on the eastern side of the climatic low-pressure system (Fig. 1), with the upper-air (above the katabatic wind layer) atmospheric flow being partially directed towards the ice sheet. Figure 12 indicates the strongest sea ice decrease along the coast of DML, especially in the region $15-45^{\circ} \mathrm{E}$. Although our analysis does not prove a causal relationship between decrease in sea ice and increase in precipitation, we argue that the joint occurrence of strong DML precipitation increases coupled with nearby strong sea ice loss reflects availability of more open water, leading to enhanced evaporation and moisture availability over and above that related to the Clausius-Clapeyron relationship. This is supported by simulated Southern Atlantic meridional moisture flux increases of $>10 \%$ during the twenty-first century (Fig. 12). Importantly, this increase is not driven by stronger meridional winds, as the simulated large-scale atmospheric circulation change is limited, but rather by enhanced moisture content of the atmosphere. 
Secondly, a warming atmosphere has a direct effect on the saturation vapour pressure, i.e. the maximal amount of moisture increases in the atmospheric column, a process especially pronounced at low temperatures. When plotting the relative precipitation change in the twenty-first century following RCP8.5 (Fig. 12), we observe that the largest relative precipitation increase is found in the cold East Antarctic interior, where air temperatures do not exceed $240 \mathrm{~K}$.

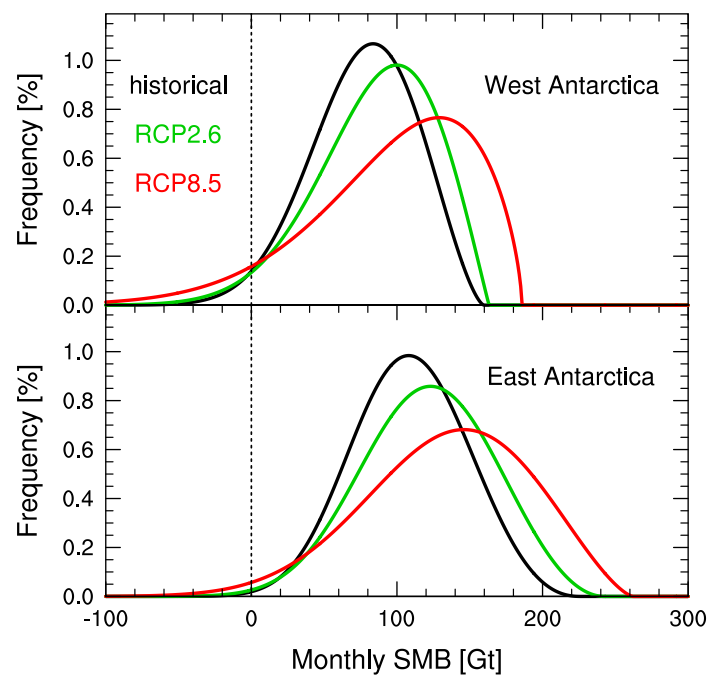

Fig. 11 Fitted general extreme value (GEV) distributions of West (above) and East (below) Antarctic area-integrated monthly SMB from historical CESM (1976-2005, black), CESM RCP2.6 (20702099, green), and CESM RCP8.5 (2070-2099, red)

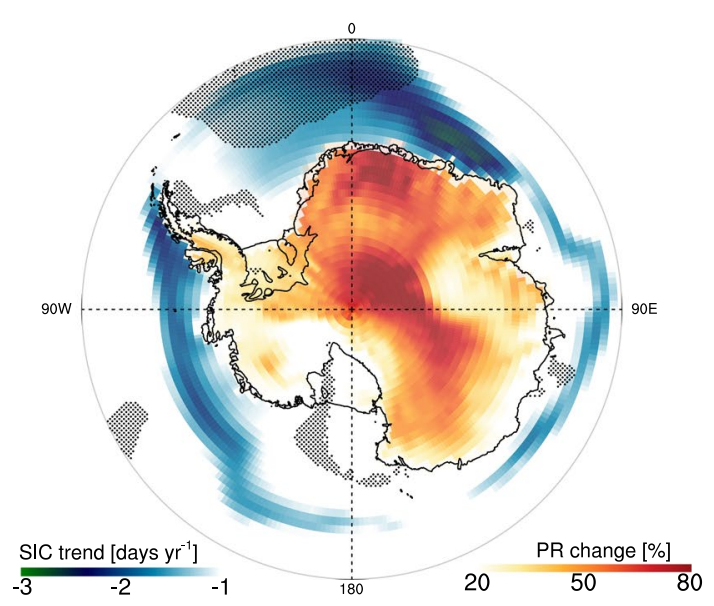

Fig. 12 Future sea ice, circulation and precipitation changes during the twenty-first century (2006-2099), according to the CESM RCP8.5 simulation. Shown on the ocean are linear change of sea ice covered days during the period 2006-2099 (colours). Dotted areas are regions where the meridional moisture flux at $850 \mathrm{hPa}$ pressure level increases with $>10 \%$. On the ice sheet, the colours show the relative precipitation change during the century

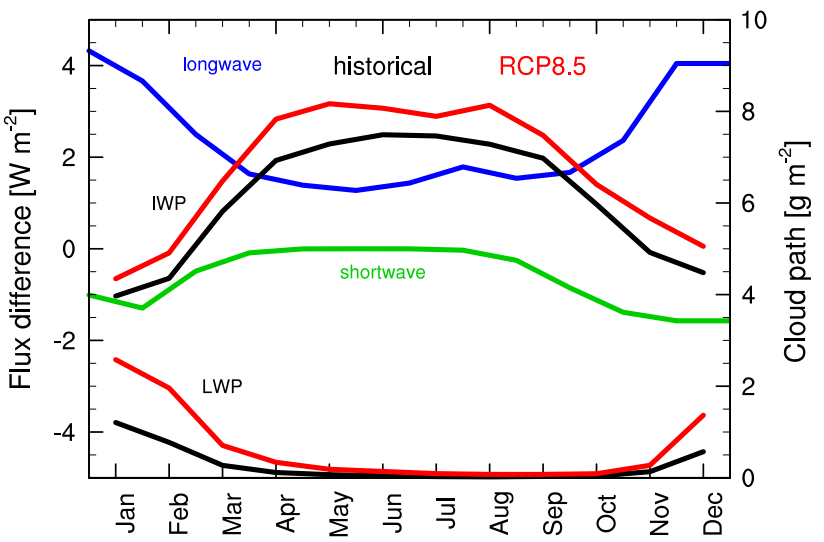

Fig. 13 Seasonal cycle of clouds and energy fluxes in CESM RCP8.5. shown are the Antarctic ice mean LWP and IWP (right axis) according to CESM historical (1976-2005, black lines) and CESM RCP8.5 (2070-2099, red lines), and difference of mean shortwave (green) and longwave (blue) flux (RCP8.5-historical)

Lastly, the third effect is that future warming of the atmospheric column not only increases the potential for more precipitation, it also changes the characteristics and frequency of Antarctic clouds. Along with bringing precipitation onto the ice sheet, clouds also strongly impact the surface energy balance (Van den Broeke et al. 2004, 2006), and thereby the energy available for heating the atmosphere, and causing sublimation and melt (Karlsson and Svensson 2010; Cesana et al. 2012; Bennartz et al. 2013). Clouds not only act as a reflector for insolation, thus limiting the amount of shortwave radiation at the surface, but also play a role as net emitters of longwave radiation. Whereas the former mechanism leads to a surface cooling and is mainly a summer phenomenon, the latter effect dampens longwave cooling, an important component of the Antarctic ice sheet surface energy balance (Fig. 4) present year-round.

The vertically integrated amount of water and ice contained in clouds, or cloud liquid (ice) water path (LWP, IWP), depends on the cloud structure and occurrence frequency and atmospheric thermodynamics (Turner 2007). Averaged over Antarctica, CESM simulates around $4 \mathrm{~g} \mathrm{~m}^{2}$ IWP in summer, increasing to $8 \mathrm{~g} \mathrm{~m}^{2}$ in winter. LWP, in contrast, is essentially zero in winter and $\sim 0.5-1 \mathrm{~g} \mathrm{~m}^{2}$ in summer (Fig. 13). This indicates that total simulated cloud water is larger in winter than in summer, but that the vast majority of clouds consist only of ice crystals. In the RCP8.5 scenario, CESM predicts a large increase of LWP in summer of $\sim 1.5-2 \mathrm{~g} \mathrm{~m}^{2}$ and only a minor increase of IWP, mainly in winter (Fig. 13). Since liquid water efficiently absorbs longwave energy (Bennartz et al. 2013) this leads to an increase in the downward net longwave flux at the surface ( $1.5 \mathrm{~W}$ in winter to $>4 \mathrm{~W}$ in summer), and a corresponding increase in the net longwave flux. Although 
the amount of liquid water contained in the clouds increases, CESM does not simulate more frequent cloudiness over Antarctica in the RCP scenarios (not shown); therefore, the decrease in net shortwave flux is much more modest $(0-1 \mathrm{~W})$ and does not compensate enhanced longwave flux at the surface. This illustrates that atmospheric warming also indirectly contributes to surface warming of the AIS surface, through changing the composition of Antarctic clouds.

\section{Discussion and conclusions}

This paper presents the recent, present-day and future (1850-2100) climate and SMB of the Antarctic ice sheet, as simulated by the Community Earth System Model (CESM), version 1.1.2. We evaluated the CESM output using observational datasets, atmospheric reanalyses, and the regional climate model RACMO2 and show that CESM is relatively well able to simulate present-day climate, sea ice cover and large-scale atmospheric circulation of the AIS and its surroundings.

The observed recent increase in Antarctic sea ice cover in the last decades is however not simulated by CESM, which is a general deficiency of state-of-the-art CMIP5 models. On the other hand, recent studies question the significance of the observed trend with respect to natural variability (Polvani and Smith 2013) due to the limited temporal coverage (Meier et al. 2013; Gagné et al. 2015), in particular as the satellite-derived products appear to be sensor-dependent (Eisenman et al. 2014). If the trend is indeed significant and externally forced, the most frequently stated mechanism for the observed increase in Antarctic sea ice is the depletion of stratospheric ozone, leading to enhanced westerly circulation in the atmosphere (Turner et al. 2009). Ozone depletion is prescribed to CESM, but it does not simulate Antarctic sea ice growth. A possible explanation of the model bias might be related to the overestimated zonal atmospheric pressure response to anthropogenic climate change, a bias common to many climate models (Haumann et al. 2014), thus reducing poleward heat and moisture advection.

Here we show that, both responding to increasing atmospheric temperatures sea-ice changes and Antarctic SMB are correlated in CESM, not only on the regional, but also on the continental scale. Together with the unrealistic sea ice loss, this aids in explaining the simulated increase in AIS SMB at the end of the twentieth century and early twentyfirst century, for which no proof is found in either observations or regional climate simulations (apart from local trends; Monaghan et al. 2006; Lenaerts et al. 2012a).

CESM predicts a substantial increase in both Antarctic precipitation and surface melt under warming conditions.
Enhanced precipitation will primarily fall in the form of snowfall in East Antarctica, in contrast to melt that mainly occurs in West Antarctica and on ice shelves. CESM thus foresees an intensification of the Antarctic hydrological cycle in the future, with wetter, snowfall-rich winters on one hand, and warmer, melt-rich summers on the other.

Although model biases remain in CESM, we have shown that it shows great potential to simulate present-day Antarctic surface climate and SMB. An important drawback of this study is associated to the limited snowpack thickness in CESM, being $1 \mathrm{~m}$ w.e., which substantially reduces the refreezing potential of the firn. In reality, the Antarctic snowpack is much thicker, with a large refreezing capacity. This implies that CESM converts meltwater production too easily into runoff; in reality, the increase of runoff will be delayed by refreezing. This effect has been demonstrated by Ligtenberg et al. (2013), a study that used a model allowing for more realistic storage of meltwater. Their findings should motivate intensified CESM development to include a multi-layered snow model with enhanced vertical resolution (Reijmer et al. 2012). Additionally, we plan future model improvements focusing on CAM5 cloud microphysics, in order to reduce the longwave flux bias. These future model improvements will allow use of CESM to detect and attribute past, present and future climate change on Antarctica and the impact of AIS SMB on global sea level, to assess the role of ozone depletion and recovery on AIS climate, and to better qualify the role of Antarctica in the global climate system.

Acknowledgments This study is funded by Utrecht University through its strategic theme Sustainability, sub-theme Water, Climate \& Ecosystems. This work was carried out under the program of the Netherlands Earth System Science Centre (NESSC), financially supported by the Ministry of Education, Culture and Science (OCW). The CESM simulations are performed on the SurfSARA high-performance Cartesius system, with support from NWO Exacte Wetenschappen. Jan Lenaerts is supported by NWO ALW through a Veni postdoctoral grant. Jeremy Fyke is supported by the Regional and Global Climate Modeling Project of the US Department of Energy Biological and Environmental Research Program. We thank Bill Sacks (NCAR), Dave Lawrence (NCAR) and Mark Flanner (University of Michigan) for their valuable input. Graphics in this paper were constructed using the NCAR Command Line software [NCL version 6.2.1, UCAR/NCAR/CISL/VETS (2014)].

Open Access This article is distributed under the terms of the Creative Commons Attribution 4.0 International License (http://creativecommons.org/licenses/by/4.0/), which permits unrestricted use, distribution, and reproduction in any medium, provided you give appropriate credit to the original author(s) and the source, provide a link to the Creative Commons license, and indicate if changes were made.

\section{References}

Agosta C, Favier V, Krinner G, Gallée H, Fettweis X, Genthon C (2013) High-resolution modelling of the Antarctic surface mass balance, application for the twentieth, twenty first and twenty 
second centuries. Clim Dyn 41(11-12):3247-3260. doi:10.1007/ s00382-013-1903-9

Arneborg L, Wahlin AK, Bjork G, Liljebladh B, Orsi AH (2012) Persistent inflow of warm water onto the central Amundsen shelf. Nat Geosci 5(12):876-880. doi:10.1038/ngeo1644

Barton NP, Sa Klein, Boyle JS (2014) On the contribution of longwave radiation to global climate model biases in arctic lower tropospheric stability. J Clim 27(19):7250-7270. doi:10.1175/ JCLI-D-14-00126.1

Bengtsson L, Koumoutsaris S, Hodges K (2011) Large-scale surface mass balance of ice sheets from a comprehensive atmospheric model. Surv Geophys 32(4):459-474. doi:10.1007/ s10712-011-9120-8

Bennartz R, Shupe MD, Turner DD, Walden VP, Steffen K, Cox CJ, Kulie MS, Miller NB, Pettersen C (2013) July 2012 Greenland melt extent enhanced by low-level liquid clouds. Nature 496(7443):83-86. doi:10.1038/nature12002

Bintanja R, van Oldenborgh GJ, Drijfhout SS, Wouters B, Katsman CA (2013) Important role for ocean warming and increased iceshelf melt in Antarctic sea-ice expansion. Nat Geosci 6(5):376379. doi: $10.1038 /$ ngeo 1767

Bromwich DH, Nicolas JP, Monaghan AJ, Lazzara MA, Keller LM, Weidner GA, Wilson AB (2012) Central West Antarctica among the most rapidly warming regions on Earth. Nat Geosci 6(2):139-145. doi:10.1038/ngeo1671

Cavalieri D, Parkinson C, Gloersen P, Zwally HJ (1996) Sea ice concentrations form Nimbus-7 SMMR and DMSP SSM/I passive microwave data. http://nsidc.org/data/nsidc-0051.html

Cesana G, Kay JE, Chepfer H, English JM, de Boer G (2012) Ubiquitous low-level liquid-containing Arctic clouds: new observations and climate model constraints from CALIPSO-GOCCP. Geophys Res Lett. doi:10.1029/2012GL053385

DeConto R, Pollard D, Harwood D (2007) Sea ice feedback and Cenozoic evolution of Antarctic climate and ice sheets. Paleoceanography. doi:10.1029/2006PA001350

Dee DP, Uppala SM, Simmons AJ, Berrisford P, Poli P, Kobayashi S, Andrae U, Balmaseda MA, Balsamo G, Bauer P, Bechtold P, Beljaars ACM, van de Berg L, Bidlot J, Bormann N, Delsol C, Dragani R, Fuentes M, Geer AJ, Haimberger L, Healy SB, Hersbach H, Hólm EV, Isaksen L, Kållberg P, Köhler M, Matricardi M, McNally AP, Monge-Sanz BM, Morcrette JJ, Park BK, Peubey C, de Rosnay P, Tavolato C, Thépaut JN, Vitart F (2011) The ERA-Interim reanalysis: configuration and performance of the data assimilation system. Q J R Meteorol Soc 137(656):553597. doi: $10.1002 / \mathrm{qj} .828$

Eisenman I, Meier WN, Norris JR (2014) A spurious jump in the satellite record: has Antarctic sea ice expansion been overestimated? Cryosph 8:1289-1296. doi:10.5194/tc-8-1289-2014

English JM, Kay JE, Gettelman A, Liu X, Wang Y, Zhang Y, Chepfer $\mathrm{H}$ (2014) Contributions of clouds, surface albedos, and mixedphase ice nucleation schemes to Arctic radiation biases in CAM5. J Clim 27(13):5174-5197. doi:10.1175/JCLI-D-13-00608.1

Favier V, Agosta C, Parouty S, Durand G, Delaygue G, Gallée H, Drouet AS, Trouvilliez A, Krinner G (2013) An updated and quality controlled surface mass balance dataset for Antarctica. Cryosph 7(2):583-597. doi:10.5194/tc-7-583-2013

Flanner MG, Zender CS (2006) Linking snowpack microphysics and albedo evolution. J Geophys Res. doi:10.1029/2005JD006834

Frieler K, Clark PU, He F, Buizert C, Reese R, Ligtenberg SRM, van den Broeke MR, Winkelmann R, Levermann A (2015) Consistent evidence of increasing Antarctic accumulation with warming. Nat Clim Change 5(4):348-352. doi:10.1038/nclimate2574

Fyke JG, Vizcaíno M, Lipscomb W, Price S (2014) Future climate warming increases Greenland ice sheet surface mass balance variability. Geophys Res Lett 41(2):470-475. doi:10.1002/201 3GL058172
Gagné ME, Gillett NP, Fyfe JC (2015) Observed and simulated changes in Antarctic sea ice extent over the past 50 years. Geophys Res Lett 42(1):90-95. doi:10.1002/2014GL062231

Genthon C, Kaspari S, Mayewski PA (2005) Interannual variability of the surface mass balance of West Antarctica from ITASE cores and ERA40 reanalyses, 1958-2000. Clim Dyn 24(7-8):759-770. doi:10.1007/s00382-005-0019-2

Gettelman A, Liu X, Ghan SJ, Morrison H, Park S, Conley AJ, Klein SA, Boyle J, Mitchell DL, Li JLF (2010) Global simulations of ice nucleation and ice supersaturation with an improved cloud scheme in the Community Atmosphere Model. J Geophys Res Atmos. doi:10.1029/2009JD013797

Gorodetskaya IV, Tsukernik M, Claes K, Ralph MF, Neff WD, Van Lipzig NPM (2014) The role of atmospheric rivers in anomalous snow accumulation in East Antarctica. Geophys Res Lett 41(17):6199-6206. doi:10.1002/2014GL060881

Grieger J, Ulbrich U, Leckebusch GC (2015) Net precipitation of Antarctica: thermodynamical and dynamical parts of the climate change signal. J Clim. doi:10.1175/JCLI-D-14-00787.1

Haumann FA, Notz D, Schmidt H (2014) Anthropogenic influence on recent circulation-driven Antarctic sea ice changes. Geophys Res Lett 41(23):8429-8437

Hunke EC, Lipscomb WH (2010) CICE: the Los Alamos sea ice model, documentation and software user's manual, version 4.1. Technical report, Los Alamos National Laboratory

Huybrechts P, Gregory J, Janssens I, Wild M (2004) Modelling Antarctic and Greenland volume changes during the 20th and 21st centuries forced by GCM time slice integrations. Glob Planet Change 42(1-4):83-105

Huybrechts P, Goelzer H, Janssens I, Driesschaert E, Fichefet T, Goosse H, Loutre MF (2011) Response of the Greenland and Antarctic ice sheets to multi-millennial greenhouse warming in the earth system model of intermediate complexity LOVECLIM. Surv Geophys 32:397-416. doi:10.1007/s10712-011-9131-5

Karlsson J, Svensson G (2010) The simulation of Arctic clouds and their influence on the winter surface temperature in present-day climate in the CMIP3 multi-model dataset. Clim Dyn 36(34):623-635. doi:10.1007/s00382-010-0758-6

Kay JE, Deser C, Phillips A, Mai A, Hannay C, Strand G, Arblaster JM, Bates SC, Danabasoglu G, Edwards J, Holland M, Kushner P, Lamarque JF, Lawrence D, Lindsay K, Middleton A, Munoz E, Neale R, Oleson K, Polvani L, Vertenstein M (2014) The Community Earth System Model (CESM) large ensemble project: a community resource for studying climate change in the presence of internal climate variability. Bull Am Meteorol Soc. doi:10.1175/BAMS-D-13-00255.1

Kharin VV, Zwiers FW, Zhang X, Hegerl GC (2010) Changes in temperature and precipitation extremes in the IPCC ensemble of global coupled model simulations. J Clim 20:1419-1444

King JC, Connelley WM, Derbyshire SH (2001) Sensitivity of modelled Antarctic climate to surface and boundary layer flux parameterisations. Q J R Meteorol Soc 127(573):779-794

Krinner G, Magand O, Simmonds I, Genthon C, Dufresne JL (2007) Simulated Antarctic precipitation and surface mass balance at the end of the twentieth and twenty-first centuries. Clim Dyn 28(2-3):215-230

Krinner G, Guicherd B, Ox K, Genthon C, Magand O (2008) Influence of oceanic boundary conditions in simulations of Antarctic climate and surface mass balance change during the coming century. J Clim 21(5):938-962. doi:10.1175/2007JCLI1690.1

Krinner G, Largeron C, Ménégoz M, Agosta C, Brutel-Vuilmet C (2014) Oceanic forcing of Antarctic climate change: a study using a stretched-grid atmospheric general circulation model. J Clim 27(15):5786-5800. doi:10.1175/JCLI-D-13-00367.1

Kuipers Munneke P, Picard G, van den Broeke MR, Lenaerts JTM, van Meijgaard E (2012) Insignificant change in Antarctic 
snowmelt volume since 1979. Geophys Res Lett. doi:10.1029/2 011GL050207

Lawrence DM, Oleson KW, Flanner MG, Thornton PE, Swenson SC, Lawrence PJ, Zeng X, Yang ZL, Levis S, Sakaguchi K, Bonan GB, Slater AG (2011) Parameterization improvements and functional and structural advances in Version 4 of the Community Land Model. J Adv Model Earth Syst. doi:10.1029/2011MS00045

Lenaerts JTM, van den Broeke MR, Déry SJ, König-Langlo G, Ettema J, Kuipers Munneke P (2010) Modelling snowdrift sublimation on an Antarctic ice shelf. Cryosph 4(2):179-190. doi:10.5194/tc-4-179-2010

Lenaerts JTM, van den Broeke MR, van de Berg WJ, Van Meijgaard E, Kuipers Munneke P (2012a) A new, high-resolution surface mass balance map of Antarctica (1979-2010) based on regional atmospheric climate modeling. Geophys Res Lett. doi:10.1029/2 011GL050713

Lenaerts JTM, van den Broeke MR, Déry SJ, van Meijgaard E, van de Berg WJ, Palm SP, Sanz Rodrigo J (2012b) Regional climate modeling of drifting snow in Antarctica, part I: methods and model evaluation. J Geophys Res. doi:10.1029/2011JD016145

Lenaerts JTM, van Meijgaard E, van den Broeke MR, Ligtenberg SRM, Horwath M, Isaksson E (2013) Recent snowfall anomalies in Dronning Maud Land, East Antarctica, in a historical and future climate perspective. Geophys Res Lett 40(11):2684-2688. doi:10.1002/grl.50559

Lenaerts JTM, Brown JB, Van den Broeke MR, Matsuoka K, Drews R, Callens D, Philippe M, Gorodetskaya IV, Van Meijgaard E, Reijmer CH, Pattyn F, van Lipzig NM (2014) High variability of climate and surface mass balance induced by Antarctic ice rises. J Glaciol. doi:10.3189/2014JoG14J040

Li X, Holland DM, Gerber EP, Yoo C (2014) Impacts of the north and tropical Atlantic Ocean on the Antarctic Peninsula and sea ice. Nature 505(7484):538-42. doi:10.1038/nature12945

Ligtenberg SRM, van de Berg WJ, van den Broeke MR, Rae JGL, van Meijgaard E (2013) Future surface mass balance of the Antarctic ice sheet and its influence on sea level change, simulated by a regional atmospheric climate model. Clim Dyn 41(3-4):867884. doi:10.1007/s00382-013-1749-1

Lindvall J, Svensson G, Hannay C (2013) Evaluation of near-surface parameters in the two versions of the atmospheric model in CESM1 using flux station observations. J Clim 26(1):26-44. doi:10.1175/JCLI-D-12-00020.1

Lipscomb WH, Fyke JG, Vizcaíno M, Sacks WJ, Wolfe J, Vertenstein M, Craig A, Kluzek E, Lawrence DM (2013) Implementation and initial evaluation of the glimmer community ice sheet model in the Community Earth System Model. J Clim 26(19):73527371. doi:10.1175/JCLI-D-12-00557.1

van Loon $H$ (1967) The half-yearly oscillations in middle and high southern latitudes and the coreless winter. J Atmos Sci 24(5):472-486. doi:10.1175/1520-0469(1967)024<0472:THYO $\mathrm{IM}>2.0 . \mathrm{CO} ; 2$

Magand O, Picard G, Brucker L, Fily M, Genthon C (2008) Snow melting bias in microwave mapping of Antarctic snow accumulation. Cryosph 2(2):109-115. doi:10.5194/tc-2-109-2008

Marshall GJ, Orr A, van Lipzig NPM, King JC (2006) The impact of a changing Southern Hemisphere Annular Mode on Antarctic Peninsula summer temperatures. J Clim 19(20):5388-5404. doi:10.1175/JCLI3844.1

Meehl GA, Washington WM, Arblaster JM, Hu A, Teng H, Kay JE, Gettelman A, Lawrence DM, Sanderson BM, Strand WG (2013) Climate change projections in CESM1 (CAM5) compared to CCSM4. J Clim 26(17):6287-6308. doi:10.1175/ JCLI-D-12-00572.1

Meier WN, Gallaher D, Campbell GG (2013) New estimates of Arctic and Antarctic sea ice extent during September 1964 from recovered Nimbus I satellite imagery. Cryosph 7(2):699-705. doi:10.5194/tc-7-699-2013

Monaghan AJ, Bromwich DH, Fogt RL, Wang SH, Mayewski PA, Dixon DA, Ekaykin A, Frezzotti M, Goodwin I, Isaksson E, Kaspari SD, Morgan VI, Oerter H, Van Ommen TD, Van der Veen CJ, Wen J (2006) Insignificant change in Antarctic snowfall since the International Geophysical Year. Science 313(5788):827-831. doi:10.1126/science.1128243

Mouginot J, Rignot E, Scheuchl B (2014) Sustained increase in ice discharge from the Amundsen Sea Embayment, West Antarctica, from 1973 to 2013. Geophys Res Lett 41(5):1576-1584. doi:10. 1002/2013GL059069

Pall P, Allen MR, Stone DA (2007) Testing the Clausius-Clapeyron constraint on changes in extreme precipitation under $\mathrm{CO} 2$ warming. Clim Dyn 28(4):351-363. doi:10.1007/s00382-006-0180-2

Polvani LM, Smith KL (2013) Can natural variability explain observed Antarctic sea ice trends? New modeling evidence from CMIP5. Geophys Res Lett 40:3195-3199. doi:10.1002/grl.50578

Pritchard H, Ligtenberg S, Fricker H, Vaughan D, van den Broeke M, Padman L (2012) Antarctic ice-sheet loss driven by basal melting of ice shelves. Nature 484(7395):502-505. doi:10.1038/ nature 10968

Reijmer CH, van den Broeke MR, Fettweis X, Ettema J, Stap LB (2012) Refreezing on the Greenland ice sheet: a comparison of parameterizations. Cryosph 6(4):743-762. doi:10.5194/ tc-6-743-2012

Rignot E, Velicogna I, van den Broeke MR, Monaghan A, Lenaerts JTM (2011) Acceleration of the contribution of Greenland and Antarctic ice sheets to sea level rise. Geophys Res Lett. doi:10.1 029/2011GL046583

Sanford T, Frumhoff PC, Luers A, Gulledge J (2014) The climate policy narrative for a dangerously warming world. Nat Clim Chang 4(3):164-166. doi:10.1038/nclimate2148

Sanz Rodrigo J, Buchlin JM, van Beeck J, Lenaerts JTM, van den Broeke MR (2012) Evaluation of the antarctic surface wind climate from ERA reanalyses and RACMO2/ANT simulations based on automatic weather stations. Clim Dyn 40(1-2):353376. doi:10.1007/s00382-012-1396-y

Shepherd A, Ivins ER, Geruo A, Barletta VR, Bentley MJ, Bettadpur S, Briggs KH, Bromwich DH, Forsberg R, Galin N, Horwath M, Jacobs S, Joughin I, King MA, Lenaerts JTM, Li J, Ligtenberg SRM, Luckman A, Luthcke SB, McMillan M, Meister R, Milne G, Mouginot J, Muir A, Nicolas JP, Paden J, Payne AJ, Pritchard H, Rignot E, Rott H, Sörensen LS, Scambos TA, Scheuchl B, Schrama EJO, Smith B, Sundal AV, van Angelen JH, van de Berg WJ, van den Broeke MR, Vaughan DG, Velicogna I, Wahr J, Whitehouse PL, Wingham DJ, Yi D, Young D, Zwally HJ (2012) A reconciled estimate of ice-sheet mass balance. Science 338(6111):1183-1189. doi:10.1126/science. 1228102

Simmonds I, Wu X (1993) Cyclone behaviour response to changes in winter southern hemisphere sea-ice concentration. Q J R Meteorol Soc 119(513):1121-1148. doi:10.1002/qj.49711951313

Smith RD, Jones PW, Briegleb B, Bryan F, Danabasoglu G, Dennis J, Dukowicz J, Eden C, Fox-Kemper B, Gent P, Others (2010) The Parallel Ocean Program (POP) reference manual: ocean component of the Community Climate System Model (CCSM). Los Alamos Natl Lab LAUR-10-01853

Stearns LA (2011) Dynamics and mass balance of four large East Antarctic outlet glaciers. Ann Glaciol 52(59):116-126. doi:10.3189/172756411799096187

Sutterley TC, Velicogna I, Rignot E, Mouginot J, Flament T, van den Broeke MR, van Wessem JM, Reijmer CH (2014) Mass loss of the Amundsen Sea Embayment of West Antarctica from four independent techniques. Geophys Res Lett 41(23):8421-8428. doi:10.1002/2014GL061940 
Taylor KE, Stouffer RJ, Meehl GA (2007) A summary of the CMIP5 experiment design. World 4:1-33

Tjernström M, Sedlar J, Shupe MD (2008) How well do regional climate models reproduce radiation and clouds in the arctic? An evaluation of ARCMIP simulations. J Appl Meteorol Climatol 47(9):2405-2422. doi:10.1175/2008JAMC1845.1

Trusel LD, Frey KE, Das SB, Munneke PK, van den Broeke MR (2013) Satellite-based estimates of Antarctic surface meltwater fluxes. Geophys Res Lett 40(23):6148-6153. doi:10.1002/201 $3 \mathrm{GL} 058138$

Turner DD (2007) Improved ground-based liquid water path retrievals using a combined infrared and microwave approach. J Geophys Res 112(D15):1-15. doi:10.1029/2007JD008530

Turner J, Comiso JC, Marshall GJ, Lachlan-Cope TA, Bracegirdle T, Maksym T, Meredith MP, Wang Z, Orr A (2009) Non-annular atmospheric circulation change induced by stratospheric ozone depletion and its role in the recent increase of Antarctic sea ice extent. Geophys Res Lett. doi:10.1029/2009GL037524

UCAR/NCAR/CISL/VETS (2014) The NCAR command language (version 6.2.1 [Software]). doi:10.5065/D6WD3XH5

Van den Broeke MR (1998) The semi-annual oscillation and Antarctic climate. Part 1: influence on near surface temperatures (195779). Antarct Sci 10(2):175-183

Van den Broeke MR (2008) Depth and density of the Antarctic firn layer. Arctic, Antarct Alp Res 40(2):432-438

Van den Broeke MR, van Lipzig NPM, van Meijgaard E (2003) Factors controlling the near-surface wind field in Antarctica. Mon Weather Rev 131(4):733-743

Van den Broeke MR, Reijmer CH, van de Wal RSW (2004) Surface radiation balance in Antarctica as measured with automatic weather stations. J Geophys Res 109(D09103):1-16

Van den Broeke MR, Reijmer CH, van As D, Boot W (2006) Daily cycle of the surface energy balance in Antarctica and the influence of clouds. Int J Clim 26(12):1587-1605
Van Wessem JM, Reijmer CH, Lenaerts JTM, van de Berg WJ, van den Broeke MR, van Meijgaard E (2014) Updated cloud physics in a regional atmospheric climate model improves the modelled surface energy balance of Antarctica. Cryosph 8(1):125-135. doi: $10.5194 / \mathrm{tc}-8-125-2014$

Vaughan DG, Bamber JL, Giovinetto M, Russel J, Cooper APR (1999) Reassessment of net surface mass balance in Antarctica. J Clim 12(4):933-946

Vaughan DG, Marshall GJ, Connolley WM, Parkinson C, Mulvaney R, Hodgson DA, King JC, Pudsey CJ, Turner J (2003) Recent rapid regional climate warming on the Antarctic Peninsula. Clim Change 60(3):243-274

Vaughan DG, Comiso JC, Allison I, Carrasco J, Kaser G, Kwok R, Mote P, Murray T, Paul F, Ren J, Rignot E, Solomina O, Steffen K, Zhang T (2013) Climate change 2013: the physical science basis. Contribution of Working Group I to the Fifth Assessment Report of the Intergovernmental Panel on Climate Change, chapter Observations. Cambridge University Press, Cambridge, United Kingdom and New York, NY, USA. doi:10.1017/ CBO9781107415324.012

Visbeck M (2009) A station-based southern annular mode index from 1884 to 2005. J Clim 22(4):940-950. doi:10.1175/2008J CLI2260.1

Vizcaíno M, Lipscomb WH, Sacks WJ, van Angelen JH, Wouters B, van den Broeke MR (2013) Greenland surface mass balance as simulated by the Community Earth System Model. Part I: model evaluation and 1850-2005 results. J Clim 26(20):7793-7812. doi:10.1175/JCLI-D-12-00615.1

Zunz V, Goosse H, Massonnet F (2013) How does internal variability influence the ability of CMIP5 models to reproduce the recent trend in Southern Ocean sea ice extent? Cryosph 7(2):451-468. doi:10.5194/tc-7-451-2013 